\title{
Bacterial Laccase Mediated Inhibition of Enzymatic Browning in Apple Juice and its Sensory Evaluation
}

\author{
Ambika Verma ${ }^{1}$, Poonam Shirkot $^{1}$, Karuna Dhiman ${ }^{1}$, Neerja Rana $^{2}$ and V.K. Joshi ${ }^{3}$ \\ ${ }^{1}$ Department of Biotechnology, ${ }^{2}$ Department of Basic Sciences, ${ }^{3}$ Department of Postharvest \\ Technology, Dr. Y. S. Parmar University of Horticulture and Forestry, Nauni, Solan-173230 \\ (H.P.), India
}

*Corresponding author

\section{A B S T R A C T}

\begin{tabular}{|c|}
\hline Keywords \\
\hline $\begin{array}{l}\text { Laccase, Apple } \\
\text { juice, Phenolics, } \\
\text { Clarification, } \\
\text { Sensory evaluation }\end{array}$ \\
\hline Article Info \\
\hline $\begin{array}{l}\text { Accepted: } \\
26 \text { December } 2017 \\
\text { Available Online: } \\
\text { 10 January } 2018\end{array}$ \\
\hline
\end{tabular}

Keywords

Laccase, Apple juice, Phenolics, Clarification, Sensory evaluation

26 December 2017

10 January 2018
The present study deals with inhibition of enzymatic browning in apple juice by laccase enzyme of Pseudomonas putida LUA15.1, which was purified by using ammonium sulfate precipitation, dialysis, gel filtration chromatography and ion exchange chromatography. Purified laccase enzyme preparation was able to eliminate undesirable phenolics and resulting in clarification of apple juice, in addition to prevention of browning of apple slices/cubes successfully. One percent concentration of purified laccase enzyme preparation was the most acceptable concentration in order to maintain colour, flavour, taste and overall acceptability of apple juice in the present study. Overall, the results clearly revealed that the use of laccases for apple juice clarification is useful. The application of laccase has improved the clarity of apple juice and also improving its sensory quality characteristics. Thus, it has a large potential for the application in juice processing industry.

\section{Introduction}

Laccases (EC 1.10.3.2.) are a group of multicopper enzymes, conferred significant attention due to their ability to oxidize phenolic and nonphenolic compounds, making them very useful for various applications in several biotechnological processes. In the food industry, laccase finds application in different processes like fruit juice processing, wine stabilization, sugar beet pectin gelation, baking and in improving food sensory parameters (Minussi et al., 2002). It is well known that browning, both enzymatic and chemical, is one of the major faults in beverages (Giovanelli and Ravasini, 1993). The color and taste of fruit juices depend particularly on the phenolic compounds which should be selectively removed to prevent any alterations in taste and colour imparted mainly by the oxidation of polyphenols. Various pre and post treatments are available to avoid post-turbidity and discoloration of fruit juices. Different methods have also been used in order to prevent the decolorization and flavor alteration in beverages such as the removal of 
phenolic groups with polyvinyl polypyrrolidone, and the use of sulfur dioxide to block oxidizers, among others (Minussi et al., 2002). An alternative for the physical and chemical adsorbents could be the use of enzymes that selectively target specific polyphenols during the maderization process. These polyphenolic substances would be oxidized by the enzymes, polymerized and then removed by clarification, and laccases has been effectively used for this purpose, because laccases have potential to eliminate undesirable phenolics, responsible for browning, haze formation and turbidity development in various beverages such as clear fruit juice, beer and wine (Cantarelli and Giovanelli, 1990).Various enzymatic treatments have been proposed for fruit juice stabilization, including the use of laccase (Piacquadio et al., 1998). There are several studies in the literature which state that laccase treatment promotes wine stabilization (Cantarelli and Giovanelli, 1990; Plank and Zent, 1993; Servili et al., 2000). Some studies also shown that wines made by laccase treatment were the best and suggesting that a stable as well as high quality wine can be made with little or no added $\mathrm{SO}_{2}$ and feasibility of using laccase for phenol removal from white must have also been suggested (Maier et al., 1990; Minussi et al., 2007). Earlier studies reported various prefermentation techniques to analyze the variation in polyphenolic compounds, color parameters, and aromatic components of wines (Moreno-Pérez et al., 2013; Wang et al., 2016).

Apple juice is one of the most frequently consumed juices and a large part of harvested apples are processed to apple juice every year. Apple juice has been the most important topic of study due to its very high demand (Ozoglu et al., 2002), but enzymatic browning is one of the main causes of its quality loss. Phenolic compounds and their oxidative products present naturally in the fruit juice have been found to give colour and taste to the juice. Colour and aroma changed from an oxidation of phenolic and polyphenolic compounds by polyphenol oxidases to $o$-quinones, and a subsequent polymerization to insoluble browning pigments of melanins (Berregi et al., 2003). These changes have been reported due to the high concentration of polyphenols and referred to as enzymatic darkening. Laccase treatment has been found to remove phenols by the help of membrane filtration and hence, achieved colour stability.

Stutz (Stutz, 1993) has also been found to produce clear and stable juice concentrates with a light colour by means of ultrafiltration and laccase, without any large additional investment. Similarly, in another studies, laccase enzyme based clarification and stabilization of apple fruit juice have been reported (Ritter and Dietrich, 1996; Piacquadio et al., 1998; Bezerra et al., 2015; Lettera et al., 2016).

Sensory qualities of apple juice have also been described to be the most important factor for its high demand (Ozoglu et al., 2002) and the good sensory qualities of apple juice have been considered by consumers to be most important factor than price (Harker et al., 2002). Enzymatic browning has not only a negative effect on colour, but also impairs the various other sensory properties including taste, odour, texture etc. (Martinez et al., 1995). Many researchers have also paid attention to the changes in the qualities and the methods for preventing the qualitylosses of the product (Ozoglu et al., 2002; Joshi et al., 2011). In the present study, purified laccase enzyme preparation of Pseudomonas putida LUA15.1 was assessed for its ability to eliminate undesirable phenolics from both apple cubes and apple fruit juice, responsible for browning and turbidity development with respect to its preferable sensory evaluation. 


\section{Materials and Methods}

\section{Bacterial isolate and its maintenance}

The bacterial isolate used in study was Pseudomonas putida LUA15.1, which was isolated from rice rhizospheric soil samples of paddy fields of Una district, Himachal Pradesh (India) in the previous study, maintained and preserved in Tryptone Yeast (TY) medium at $4^{\circ} \mathrm{C}$. Tryptone Yeast medium (Givaudan et al., 1993; Sowinski et al., 2002)had the following composition: Tryptone $5.0 \mathrm{~g}$, Yeast Extract $3.0 \mathrm{~g}, 1 \mathrm{M} \mathrm{CaCl} 2$ Solution $10 \mathrm{ml}, \mathrm{CuSO}_{4} 50$ $\mathrm{mg}, 5 \mathrm{mM}$ Guaiacol and distilled water to make one litre having $\mathrm{pH} 7.0$ All the media components were procured from SRL, Mumbai (India).

\section{Laccase production and its purification}

Pseudomonas putida LUA15.1 culture was inoculated into the Tryptone Yeast (TY) broth and mixed thoroughly by keeping the flasks on a rotary shaker at $150 \mathrm{rpm}$ for 24 hours at $28^{\circ} \mathrm{C}$. The culture supernatant was obtained by centrifugation of overnight culture of Pseudomonas putida LUA15.1 at 10,000 rpm, for 10 minutes at $4^{\circ} \mathrm{C}$. This culture supernatant was used as crude extracellular laccase enzyme which was further purified by ammonium sulfate precipitation, dialysis, gel filtration chromatography and ion exchange chromatography techniques. The activity of the purified laccase after each step of purification was determined by monitoring the oxidation of ABTS (Faramarzi and Forootanfar, 2011).

\section{Laccase activity assay}

Laccase activity was determined spectrophotometrically at $420 \mathrm{~nm}$ with ABTS as a substrate. Catalase was added to the assay solution and incubated for $1 \mathrm{hr}$ at $37^{\circ} \mathrm{C}$ to remove the possible effect of $\mathrm{H}_{2} \mathrm{O}_{2}$ produced by the bacterial isolate. The reaction mixture contained $200 \mu \mathrm{l}$ aliquots of extracellular enzyme preparation and $0.2 \mathrm{mM}$ ABTS in 0.1 $\mathrm{M}$ sodium acetate buffer ( $\mathrm{pH}$ 4.5) making final volume to $1.0 \mathrm{ml}$. The reaction was held at $32^{\circ} \mathrm{C}$ for 10 mins followed by addition of 0.5 $\mathrm{ml}$ of $80 \%$ trichloroacetic acid to stop the reaction. One unit of enzyme was defined as the amount of enzyme required to oxidize 1.0 $\mu$ mol of ABTS per min. The molar extinction coefficient of ABTS was found to be 36,000 $\mathrm{M}^{-1} \mathrm{~cm}^{-1}$.

\section{Clarification of apple juice}

Purified laccase enzyme preparation was assessed for its ability to eliminate undesirable phenolics from both apple cubes and apple fruit juice, responsible for browning and turbidity development. In case of apple cubes, fresh apples were peeled and cut into small cubes in order to make treatment of these cubes with purified laccase enzyme preparation and one control was run in parallel without any treatment, followed by incubation at room temperature for 48 hrs. Effect of browning was observed visually on the apple cubes up to $48 \mathrm{hrs}$. To study the effect of purified laccase enzyme preparation on apple juice, fresh apple juice was extracted with the help of crusher and filtered by musline cloth which was treated with different concentrations of purified laccase enzyme preparation $(0.2,0.4,0.6,0.8$ and $1.0 \%)$ and one control was run in parallel without the addition of laccase enzyme preparation followed by incubation at room temperature for one week. Browning or turbidity development in apple juice was observed up to 48 hrs.

\section{Sensory evaluation}

Sensory quality is a criterion for determining the acceptability of any food or food product by the consumers. Overall acceptability of 
food in addition to quality and nutritional attributes also depends on the sensory quality. The quality of apple juice was evaluated by sensory evaluation in interval of every $24 \mathrm{hrs}$ for 7 days although the apple juice were hot fill and aseptic pack in air tight tubes so aseptically withdrawal of sample has been taken for avoiding contamination in aseptic environment. Consumer preferences for the experimental apple juice samples were found out through sensory evaluation performed at different intervals during storage by a panel of judges. The panelists were given coded samples consisting of apple juice for giving their views on overall acceptability of the fruit juice on the basis of appearance, flavor and taste. The sensory parameters of colour, flavour, taste and overall acceptability were evaluated based on 9 point Hedonic rating scale with maximum score considered as the best for apple juice (Wills et al., 1980).

\section{Results and Discussion}

\section{Production and purification of laccase enzyme from Pseudomonas putida LUA15.1}

Pseudomonas putida LUA15.1 culture was inoculated into the Tryptone Yeast (TY) broth and mixed thoroughly by keeping the flasks on a rotary shaker at $150 \mathrm{rpm}$ for 24 hours at $28^{\circ} \mathrm{C}$. The culture supernatant was obtained by centrifugation of overnight culture of Pseudomonas putida LUA15.1 at 10,000 rpm, for 10 minutes at $4^{\circ} \mathrm{C}$. This culture supernatant was used as crude extracellular laccase enzyme which was subjected to ammonium sulphate (0-90\%) saturation and it was found out that maximum laccase enzyme activity was detected in 50-90 percent level of saturation. The enzyme preparation at this stage was treated as ammonium sulphate fraction (ASF). The ASF (proteins precipitated after the overnight dialysis of $50-90 \%$ ammonium sulphate cut) exhibits the highest rate of precipitation and purified the enzyme
20.56 times with a $68.17 \%$ yield and was applied on Sephadex G-100 column equilibrated with sodium phosphate buffer ( $\mathrm{pH}$ 6.5), purified the enzyme 28.30 times with a $32.69 \%$ yield. And in the last step, the enzyme fractions obtained and concentrated from Sephadex G-100 column were applied to the DEAE sephadex ion exchange column. It was found that laccase fractions were eluted with $1.0 \mathrm{M} \mathrm{NaCl}$ gradient which further purified laccase with 48.49 times purification and $10.08 \%$ yield. Laccases have also been produced and purified from various bacterial isolates like Azospirillum lipoferum, Marinomonas mediterranea, Bacillus subtilis, $\gamma$-Proteobacterium JB, Brevibacillus sp. (Z1), Serratia marcescens (MTCC 4842), Bacillus subtilis MTCC 2414, Bacillus tequilensis SN4 using ammonium sulphate precipitation, gel filteration chromatography, Sephadex G-100, DEAE-cellulose chromatography etc (Diamantidis et al., 1999; Martins et al., 2002; Bains et al., 2003; Bozoglu et al., 2013; Kaira et al., 2015; Muthukumarasamy et al., 2015; Sondhi et al., 2015).

Clarification of apple juice and its sensory evaluation

Purified laccase enzyme preparation of Pseudomonas putida LUA15.1 was assessed for its ability to eliminate undesirable phenolics from both apple cubes and apple fruit juice, responsible for browning and turbidity development and it has been observed that purified laccase enzyme preparation of Pseudomonas putida LUA15.1 has been able to eliminate undesirable phenolics and resulted in clarification of apple juice, in addition to prevention of browning of apple slices/cubes successfully (Figure 1).

For sensory evaluation, effect of purified laccase enzyme preparation on apple juice was assessed. Fresh apple juice was extracted and treated with different concentrations of 
purified laccase enzyme preparation in the range $0.2-1.0 \%$ and one control was run in parallel without addition of any laccase enzyme preparation followed by incubation at $3 \pm 1^{\circ} \mathrm{C}$ for 7 days. The sensory parameters of colour, flavour, taste and overall acceptability were evaluated at an interval of $24 \mathrm{hrs}$ for 7 days with ten panelists based on 9 point Hedonic rating scale with maximum score considered as the best for apple juice.

\section{Colour rating}

The initial colour score for the apple juice samples treated with purified laccase enzyme preparation (0.2-1.0\%) ranged from 8.1 to 8.5 at 0 days and after 7 days it was found to be vary from 6.6 to 8.0. While in control sample (without laccase enzyme treatment) the sensory colour score at 0 days was found to be 8.0 and after 7 days it was found to be 4.5. The colour changed significantly during the storage of apple juice between 0-7 days because of browning taking place in apple juice samples due to increase in polyphenol oxidase (PPO) activity (Figure 2). There was little decrease in colour score of laccase treated samples as compared to control, where higher decrease in the colour score was observed, due to the release of undesirable phenolics responsible for browning and turbidity development in the apple juice, indicating elimination of undesirable phenolics responsible for browning and turbidity development in juice samples treated with purified laccase enzyme preparation as compared to control sample (Table 1).

Table.1 Colour score of apple juice for sensory evaluation

\begin{tabular}{|c|c|c|c|c|c|c|c|c|c|c|}
\hline \multirow{3}{*}{$\begin{array}{c}\text { Sr. } \\
\text { No. }\end{array}$} & \multirow{3}{*}{$\begin{array}{c}\text { Laccase } \\
\text { concentration } \\
(\%)\end{array}$} & \multicolumn{8}{|c|}{ Colour rating } & \multirow[t]{3}{*}{ Mean } \\
\hline & & \multicolumn{8}{|c|}{ Storage interval in days } & \\
\hline & & $\mathbf{0}$ & 1 & 2 & 3 & 4 & 5 & 6 & 7 & \\
\hline 1. & Control & 8.0 & 7.5 & 6.2 & 5.9 & 5.6 & 5.2 & 4.8 & 4.5 & 5.96 \\
\hline 2. & 0.2 & 8.1 & 7.8 & 7.4 & 7.1 & 7.0 & 6.8 & 6.7 & 6.5 & 7.17 \\
\hline 3. & 0.4 & 8.2 & 7.9 & 7.5 & 7.4 & 7.3 & 7.2 & 7.1 & 7.0 & 7.45 \\
\hline 4. & 0.6 & 8.3 & 8.0 & 7.6 & 7.5 & 7.4 & 7.3 & 7.2 & 7.1 & 7.55 \\
\hline 5. & 0.8 & 8.4 & 8.2 & 8.1 & 8.0 & 7.8 & 7.6 & 7.4 & 7.2 & 7.83 \\
\hline 6. & 1.0 & 8.5 & 8.4 & 8.3 & 8.3 & 8.2 & 8.2 & 8.1 & 8.0 & 8.25 \\
\hline
\end{tabular}

Table.2 Flavour score of apple juice for sensory evaluation

\begin{tabular}{|c|c|c|c|c|c|c|c|c|c|c|}
\hline \multirow{3}{*}{$\begin{array}{l}\text { Sr. } \\
\text { No. }\end{array}$} & \multirow{3}{*}{$\begin{array}{c}\text { Laccase } \\
\text { concentration } \\
(\%)\end{array}$} & \multicolumn{8}{|c|}{ Flavour rating } & \multirow[t]{3}{*}{ Mean } \\
\hline & & \multicolumn{8}{|c|}{ Storage interval in days } & \\
\hline & & $\mathbf{0}$ & 1 & 2 & 3 & 4 & 5 & 6 & 7 & \\
\hline 1. & Control & 8.0 & 7.6 & 6.0 & 5.5 & 5.1 & 4.8 & 4.4 & 4.0 & 5.67 \\
\hline 2. & 0.2 & 8.0 & 7.8 & 7.4 & 7.2 & 7.0 & 6.8 & 6.6 & 6.4 & 7.15 \\
\hline 3. & 0.4 & 8.0 & 7.7 & 7.5 & 7.3 & 7.3 & 7.1 & 7.0 & 6.8 & 7.33 \\
\hline 4. & 0.6 & 8.0 & 7.9 & 7.5 & 7.3 & 7.2 & 7.1 & 7.1 & 7.0 & 7.38 \\
\hline 5. & 0.8 & 8.1 & 8.0 & 7.9 & 7.9 & 7.8 & 7.7 & 7.6 & 7.5 & 7.81 \\
\hline 6. & 1.0 & 8.2 & 8.2 & 8.1 & 8.1 & 8.0 & 8.0 & 7.9 & 7.8 & 8.03 \\
\hline
\end{tabular}


Table.3 Taste score of apple juice for sensory evaluation

\begin{tabular}{|c|c|c|c|c|c|c|c|c|c|c|}
\hline \multirow{3}{*}{$\begin{array}{l}\text { Sr. } \\
\text { No. }\end{array}$} & \multirow{3}{*}{$\begin{array}{c}\text { Laccase } \\
\text { concentration } \\
(\%)\end{array}$} & \multicolumn{8}{|c|}{ Taste rating } & \multirow[t]{3}{*}{ Mean } \\
\hline & & \multicolumn{8}{|c|}{ Storage interval in days } & \\
\hline & & $\mathbf{0}$ & 1 & 2 & 3 & 4 & 5 & 6 & 7 & \\
\hline 1. & Control & 7.5 & 7.0 & 6.3 & 5.8 & 5.5 & 4.6 & 4.3 & 4.0 & 5.62 \\
\hline 2. & 0.2 & 7.5 & 7.3 & 7.1 & 6.8 & 6.5 & 6.3 & 6.1 & 6.1 & 6.71 \\
\hline 3. & 0.4 & 7.5 & 7.4 & 7.3 & 7.3 & 7.2 & 7.2 & 7.1 & 7.1 & 7.26 \\
\hline 4. & 0.6 & 7.5 & 7.4 & 7.4 & 7.3 & 7.3 & 7.2 & 7.2 & 7.1 & 7.30 \\
\hline 5. & 0.8 & 7.6 & 7.6 & 7.5 & 7.5 & 7.4 & 7.4 & 7.3 & 7.3 & 7.45 \\
\hline 6. & 1.0 & 7.6 & 7.6 & 7.6 & 7.5 & 7.5 & 7.5 & 7.4 & 7.4 & 7.51 \\
\hline
\end{tabular}

Table.4 Overall acceptability score of apple juice for sensory evaluation

\begin{tabular}{|c|c|c|c|c|c|c|c|c|c|c|}
\hline \multirow{3}{*}{$\begin{array}{l}\text { Sr. } \\
\text { No. }\end{array}$} & \multirow{3}{*}{$\begin{array}{c}\text { Laccase } \\
\text { concentration } \\
(\%)\end{array}$} & \multicolumn{8}{|c|}{ Overall acceptability } & \multirow[t]{3}{*}{ Mean } \\
\hline & & \multicolumn{8}{|c|}{ Storage interval in days } & \\
\hline & & $\mathbf{0}$ & $\mathbf{1}$ & 2 & 3 & 4 & 5 & 6 & 7 & \\
\hline 1. & Control & 7.83 & 7.36 & 6.16 & 5.73 & 5.50 & 4.86 & 4.46 & 4.16 & 5.75 \\
\hline 2. & 0.2 & 7.86 & 7.63 & 7.20 & 7.03 & 6.83 & 6.63 & 6.46 & 6.33 & 6.99 \\
\hline 3. & 0.4 & 7.90 & 7.66 & 7.43 & 7.33 & 7.26 & 7.16 & 7.06 & 6.96 & 7.34 \\
\hline 4. & 0.6 & 7.93 & 7.76 & 7.50 & 7.36 & 7.26 & 7.20 & 7.16 & 7.06 & 7.40 \\
\hline 5. & 0.8 & 8.03 & 7.93 & 7.83 & 7.80 & 7.66 & 7.56 & 7.43 & 7.33 & 7.41 \\
\hline 6. & 1.0 & 8.10 & 8.06 & 8.00 & 7.96 & 7.90 & 7.90 & 7.80 & 7.73 & 7.93 \\
\hline
\end{tabular}

Figure.1 Effect of purified laccase enzyme preparation of Pseudomonas putida LUA15.1 (A) on browning of apple cubes (B) on apple juice
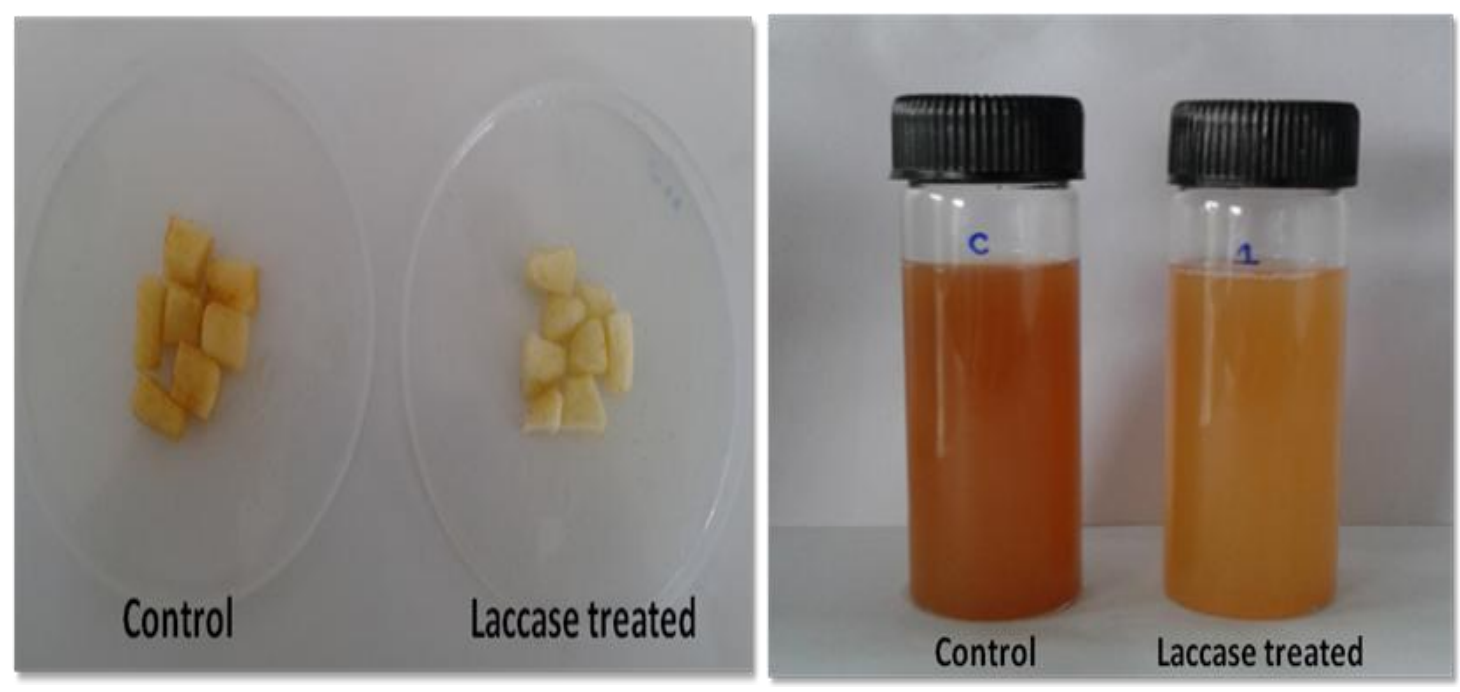
Figure.2 Effect of different concentrations of purified laccase enzyme preparations of Pseudomonas putida LUA15.1 on apple juice:(a) Control (without laccase treatment) (b) $0.2 \%$ (c) $0.4 \%$ (d) $0.6 \%$ (e) $0.8 \%$ (f) $1.0 \%$ purified laccase enzyme preparation

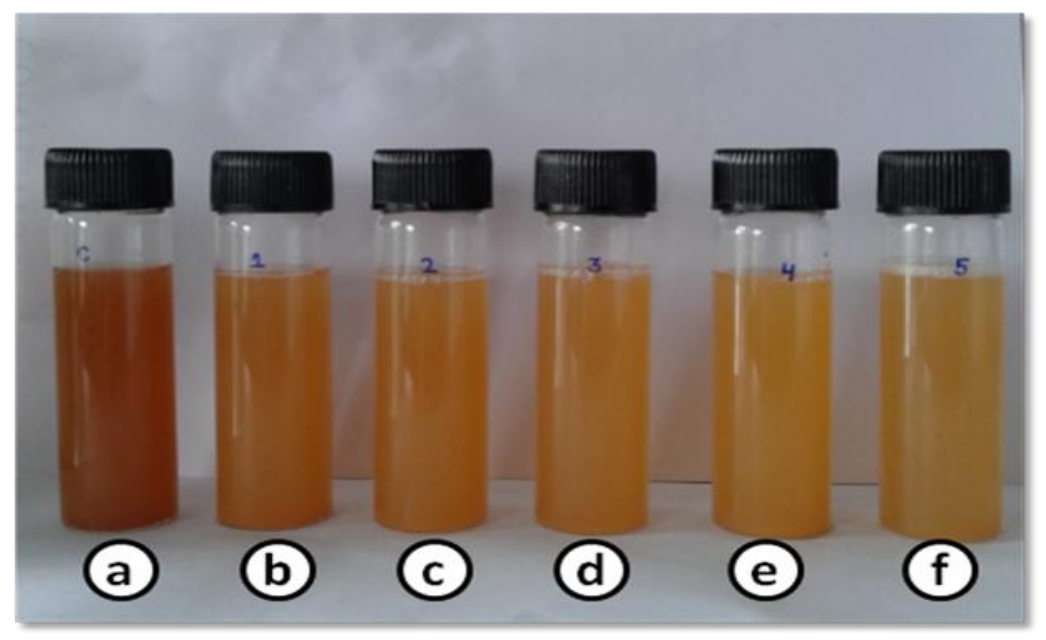

\section{Flavour rating}

The initial flavour score for the apple juice samples treated with purified laccase enzyme preparation $(0.2-1.0 \%)$ ranged from 8.0 to 8.2 at 0 days and after 7 days it was found to range from 6.4 to 7.8 . While in control sample (without laccase enzyme treatment) the sensory flavour score at 0 days was found to be 8.0 and after 7 days it was found to be 4.0 . The flavour decreased significantly during the storage of apple juice for 0-7 days. This decrease could be due to high level of acid that reacts with the product unpleasant volatile odour, loss of volatile aromatic substances responsible for flavour and could be due to slight fermentation of juice and gas production. This also indicated positive effect of purified laccase enzyme preparation on flavour of laccase treated apple juice sample as compared to control sample. A change in flavour score during the storage as compared to control has been presented in table 2 .

\section{Taste rating}

The initial taste score for the apple juice samples treated with purified laccase enzyme preparation was found to range from 7.5 to 7.6 at 0 days and after 7 days it was found to range from 6.1 to 7.4 . While in control sample (without laccase enzyme treatment) the sensory taste score at 0 days was 7.5 and after 7 days it was found to be 4.0. The taste decreased significantly during the storage of apple juice between 0-7 days. This decrease could be due to the loss of volatile aromatic substances responsible for taste and due to decrease in $\mathrm{pH}$, juice became more acidic. This also indicated the positive effect of purified laccase enzyme preparation on taste of laccase treated apple juice samples as compared to control sample. A change in taste score during the storage as compared to control has been presented in table 3 .

\section{Overall acceptability rating}

Data on overall acceptability rating of apple fruit juice, as affected by purified laccase enzyme preparation during storage (Table 4) showed that apple juice samples treatedwith1.0\% concentration of purified laccase enzyme preparation was the most acceptable obtaining a mean score of 7.93 after 7 days of storage at $3+1^{\circ} \mathrm{C}$ and hence it 
was the most effective treatment in maintaining overall acceptability of the apple juice (Figure 2).

It was followed by the treatments containing $0.8 \%$ and $0.6 \%$ concentration of purified laccase enzyme preparation with overall acceptability rating 7.41 and 7.40 respectively. One percent concentration of purified laccase enzyme preparation treated juice sample generally exhibited maximum rating on all sampling dates whereas other treatments were found to be effective to a lesser extent. On the other hand the lowest overall acceptability rating (5.75) was recorded for control sample and it was significantly lower in comparison to all the treatments (Figure 2). Thus in the present study, it was found that purified laccase enzyme preparation of Pseudomonas putida LUA15.1 was able to eliminate undesirable phenolics and resulting in clarification of apple juice, in addition to prevention of browning of apple slices/cubes successfully. One percent concentration of purified laccase enzyme preparation was the most acceptable concentration in order to maintain colour, flavour, taste and overall acceptability of apple juice in the present study.

Similarly, earlier studies also reported, laccase enzyme based clarification and stabilization of apple fruit juice (Ritter and Dietrich, 1996; Piacquadio et al., 1998; Bezerra et al., 2015; Lettera et al., 2016). Whereas, many studies reported laccase enzyme treatment for controlled haze formation and browning in addition to clarification and stabilization of sour cherry and pomegranate juice have (Artik et al., 2004; Neifar et al., 2009). Many studies also reported enzymes based clarification of four kinds of fruits juices, i.e., tangerine, orange, grapefruit and apple (Lu et al., 2009).Sensory qualities of apple juice have also been reported to be improved with the help of enzymes (Joshi and Bhutani, 1991; Joshi et al., 2011). Clarification, of cashew apple juice and evaluation of its sensory attributes in terms of color, flavor, taste, sedimentation, and overall acceptability have been reported (Talasila et al., 2012). Recent studies also reported sensory attributes, such as color, aroma, taste, and overall acceptance for various seed juices (Park et al., 2017).

In conclusion, there was a significant increase in the clarification of apple juice with the use of $1.0 \%$ laccase enzyme. Clarity of treated juice improved because of the removal of phenolic compounds in the juice. Thus, the juice becomes clearer and superior in colour, flavor, taste and appearance in terms of sensory qualities improved the overall quality of apple juice. Overall, the results clearly revealed that the use of laccases for apple juice clarification is useful. It could also be used economically for the processing purpose. The application of laccase has improved the clarity of apple juice and also improving its sensory quality characteristics. Thus, it has a large potential for the application in juice processing industry.

\section{Acknowledgement}

The author acknowledges the financial assistance received from Department of Biotechnology at Dr. Y. S. Parmar University of Horticulture and Forestry, Nauni, Solan, Himachal Pradesh to carry out the whole part of this research work.

\section{References}

Artik, N., Karhan, M. and Aydar, G., 2004, Effects of polyphenoloxidase (Laccase) application on clarity, stability of sour cherry juice. Journal of Food Technology, 2: 237-243.

Bains, J., Capalash, N. and Sharma, P., 2003, Laccase from a non-melanogenic, alkalotolerant $\gamma$-proteobacterium JB 
isolated from industrial wastewater drained soil. Biotechnology Letters, 25: 1155-1159.

Berregi, I., Santos, J. I., Campo, G., Miranda, J. I. and Aizpurua, J. M., 2003, Quantitation determination of chlorogenic acid in cidar apple juices by ${ }^{1} \mathrm{H} \quad \mathrm{NMR}$ spectrometry. Analytica Chemica Acta., 486: 269-274.

Bezerra, T. M. S., Bassan, J. C., Santos, V. T. O., Ferraz, A. andMonti, R., 2015, Covalent immobilization of laccase in green coconut fiber and use in clarification of apple juice. Process Biochemistry, 50: 417-423.

Bozoglu, C., Adiguzel, A., Nadaroglu, H., Yanmis, D. and Gulluce, M., 2013, Purification and characterization of laccase from newly isolated thermophilic Brevibacillus sp. $\left(\mathrm{Z}_{1}\right)$ and its applications in removal of textile dyes. Research Journal of Biotechnology, 8: 56-66.

Cantarelli, C. and Giovanelli, G., 1990, White wine stabilization treatments by enzymic oxidation of polyphenols. Reverend Oenol, 127: 15-25.

Diamantidis, G., Effosse, A., Potier, P. and Bally, P., 1999, Purification and Characterization of the first bacterial laccase in the rhizospheric bacterium Azospirillum lipoferum. Soil Biology and Biochemistry, 32: 919-927.

Faramarzi, M. A. and Forootanfar, H., 2011, Biosynthesis and characterization of gold nanoparticles produced by laccase from Paraconiothyrium variabile. Coll. Surf. B Bioint., 87: 23-27.

Giovanelli, G. andRavasini, G., 1993, Apple juice stabilization by combined enzyme-membrane filtration process. Lebensmittel-Wissenschaft and Technologie, 26: 1-7.

Givaudan, A., Effosse, A., Faure, D., Potier, P., Bouillant,M. L. and Bally, R., 1993, Polyphenol oxidase in Azospirillum lipoferum isolated from rice rhizosphere: evidence for laccase activity in non-motile strains of Azospirillum lipoferum. FEMS Microbiology Letters 108: 205-210.

Harker, F. R., Marsh, K. B., Young, H., Murray, S. H., Gunson, F. A. and Walker, S. B., 2002, Sensory interpretation of instrumental measurements 2: sweet and acid taste of apple juice. Postharvest Biology and Technology, 24: 241-250.

Joshi, V. K. and Bhutani, V. P., 1991, The influence of enzymatic clarification on the fermentation behaviour, composition and sensory qualities of apple wine. Sciences Des Aliments, 11: 491-498.

Joshi, V. K., Parmar, M. and Rana, N., 2011, Purification and characterization of pectinase produced from apple pomace and evaluation of its efficacy in fruit juice extraction and clarification. Indian Journal of Natural Products and Resources, 2: 189-197.

Kaira, G. S., Dhakar, K. and Pandey, A., 2015, A psychrotolerant strain of Serratia marcescens (MTCC 4822) produces laccase at wide temperature and $\mathrm{pH}$ range. $A M B$ Express, DOI 10.1186/s13568-014-0092-1.

Lettera, V., Pezzella, C., Cicatiello, P., Piscitelli, A., Giacobelli, V. G., Galano, E., Amoresano, A. and Sannia, G., 2016,Efficient immobilization of a fungal laccase and its exploitation in fruit juice clarification. Food Chemistry, 196: 1272-1278.

Lu, X., Lin, J., Wang, C., Du, X. and Cai, J., 2009, Purification and characterization of exo-polygalacturonase from Zygoascus hellenicus V25 and its potential application in fruit juice clarification. Food Science and Biotechnology, 25: 1379-1385.

Maier, G., Mayer, P., Dietrich, H. and 
Wucherpfenning, $\quad$ K., $\quad 1990$, Polyphenoloxidases and their application in fruit juice stabilization. Fluessiges-Obst, 57: 230-251.

Martinez, M. V. and Whitaker, J. R., 1995, The biochemistry and control of enzymatic browning. Trends in Food Science and Technology, 6: 195-220.

Martins, L. O., Soares, C. M., Pereira, M. M., Teixeira, M., Costa, Jones, G. H. and Henriques, A. O., 2002,Molecular and biochemical characterization of a highly stable bacterial laccase that occurs as a structural component of the Bacillus subtilis endospore coat. The Journal of Biological Chemistry, 277: 18849-18859.

Minussi, R. C., Pastore, G. M. and Duran, N., 2002, Potential applications of laccase in the food industry. Trends in Food Science and Technology,13: 205216.

Minussi, R. C., Rossi, M., Bologna, L., Rotilio, D., Pastore, G.M. and Duran, N., 2007, Phenols removal in musts: Strategy for wine stabilization by laccase. Journal of Molecular Catalysis B: Enzymatic, 45: 102-107.

Moreno-Pérez, A., Vila-López, R., Fernández-Fernández, J. I., MartínezCutillas, A. and Gil-Muñoz, R., 2013, Influence of cold pre-fermentation treatments on the major volatile compounds of three wine varieties. Food Chemistry, 139: 770-776.

Muthukumarasamy, N. P., Jackson, B., Raj, A. J. and Sevanan, M., 2015, Production of extracellular laccase from Bacillus subtilis MTCC 2414 using agro residues as apotential substrate. Biochemistry Research Journal, doi.10.1155/2015/765190.

Neifar, M., Ghorbel, R. E. andKamaun, A., 2009, Effective clarification of pomegranate juice using laccase treatment optimized by response surface methodology followed by ultrafiltration. Journal of Food Process Engineering, 34: 1199-1219.

Ozoglu, H. and Bayindirh, A., 2002, Inhibition of enzymatic browning in cloudy apple juice with selected antibrowning agents. Food control, 13: 213-221.

Park, S. H., Park, H. J., Kim, J. Y., Lee, S. H., Jang, J. S. and Lee, M. H., 2017, Mixed seeds juice with high antioxidant capacity and digestive enzyme activity and its application. Food Science and Biotechnology,26: 237-244.

Piacquadio, P., De Stefano, G., Sammartino, M. and Sciancalepore, V., 1998, Apple juice stabilization by laccase (EC 1.10.3.2) immobilized on metalchelate regenerable carries. Industrie Delle Bevande, 27: 378-383.

Piacquadio, P., De Stefano, G., Sammartino, M. and Sciancalepore, V., 1998. Apple juice stabilization by laccase (EC 1.10.3.2) immobilized on metal chelate regenerable carries. Industrie Delle Bevande, 27: 378-383.

Plank, P. F. H. and Zent, L. B., 1993, Use of enzymes in wine making and grape processing. Technological advances. In: Gump BH and Pruett DJ (eds.): Analysis, Characterization, and Technological Advances. ACS Symposium Series pp.181-196.

Ritter, G. and Dietrich, I., 1996, The effect of modern techniques on the content of important plant phenols in apple juice. Fluessiges-Obst,63: 256-263.

Servili, M., De Stefano, G., Piacquadio, P. and Sciancalepore, V., 2000, A novel method for removing phenols from grape must. American Journal of Enology and Viticulture, 51: 357-361.

Sondhi, S., Sharma, P., George, N., Chauhan, P. S., Puri, N. and Gupta, N., 2015, An extracellular, thermoalkali stable laccase from Bacillus tequilensis 
SN4, with potential to biobleach softwood pulp. 3 Biotech, 5: 175-185.

Sowinski, S. C., Drets, G. M. and Okon, Y., 2002, Laccase activity in melaninproducing strains of Sinorhizobium meliloti. FEMS Microbiology Letters, 209: 119-125.

Stutz, C., 1993, The use of enzymes in ultrafiltration. Fruit Processing,3: 248252.

Talasila, U., Vechalapu, R. R. and Shaik, K. B., 2012, Clarification, Preservation, and Shelf Life Evaluation of Cashew Apple Juice. Food Science and Biotechnology, 21: 709-714.
Wang, J., Huo, S., Zhang, Y., Liu, Y. and Fan, W., 2016, Effect of Different Prefermentation Treatments on Polyphenols, Color, and Volatile Compounds of Three Wine Varieties. Food Science and Biotechnology,25: 735-743.

Wills, R. B. H., Bembridge, P. A. and Scott, K.J., 1980, Use of fleshfirmness and other objective tests to determine consumer acceptability of delicious apple. Australian Journal of Experimental Agriculture and Animal Husbandry, 20: 252-256.

\section{How to cite this article:}

Ambika Verma, Poonam Shirkot, Karuna Dhiman, Neerja Rana and V.K. Joshi. 2018. Bacterial Laccase Mediated Inhibition of Enzymatic Browning in Apple Juice and Its Sensory Evaluation. Int.J.Curr.Microbiol.App.Sci. 7(01): 3371-3381.

doi: https://doi.org/10.20546/ijcmas.2018.701.399 